\title{
Promising ichthyologic studies in Lake Baikal: fundamental and applied aspects
}

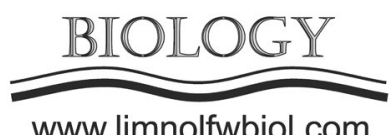

www.limnolfwbiol.com

\author{
Dzyuba E.V., Bogdanov B.E., Sapozhnikova Yu.P.*, Sukhanova L.V., Anoshko P.N., \\ Khanaev I.V. ${ }^{\oplus}$, Kirilchik S.V. ${ }^{\oplus}$ \\ Limnological Institute, Siberian Branch of the Russian Academy of Sciences, Ulan-Batorskaya Str., 3, Irkutsk, 664033, Russia
}

\begin{abstract}
Promising areas of ichthyologic research in Lake Baikal have been examined. Particular attention is being paid to the technology of remote fish census, including hydroacoustic methods and the method of quantitative environmental DNA analysis. These technologies may provide information on the status of artificially reproducible populations in reservoirs for developing a proper fishing strategy. The areas of application of molecular genetic methods for solving applied problems in creating the biological bases of fisheries, studying diseases, associated microflora and parasitic fauna, as well as for identifying fish feed objects have been determined. Studies aimed at restoring and maintaining the populations of rare and endangered fish species using artificial reproduction methods, including breeding, hybridization, hormonal stimulation of spawning producers, cryopreservation of sexual products, individual tagging, etc., are discussed. Prospects of mobile remote underwater video monitoring systems, the EthoStudio software package and the holography method to simulate sensory reaction in studying mechanisms of adaptations of fish in natural environment and to develop criteria for assessing their stability in aquaculture conditionshave been reviewed. Combining ethological studies and in-depth integrated morphological, molecular-genetic and physiological-biochemical screening of Baikal fish that would allow to better understand fundamental evolutionary processes responsible for the formation of behavioral adaptations, creation and maintenance of genetic diversity within and between populations in the natural environment, as well as developing recommendations on the introduction of state-of-theart scientific monitoring approaches into aquaculture are very promising.
\end{abstract}

Keywords: ichthyological studies, hydroacoustic methods, environmental DNA, molecular genetic methods, common garden experiments, video monitoring systems, Lake Baikal

There are almost three hundred years of ichthyologic studies in Lake Baikal and in its catchment area. During this time, they moved away from brief faunal reviews and taxonomic descriptions towards integrated and interdisciplinary studies oriented to fish biodiversity, systematics, phylogeny, evolution, ecology, morphology and physiology. Results of these studies are published in many papers. They constitute a basis of the current knowledge about fish of Lake Baikal, and they will be still in demand in the future. The importance of the ichthyologic research in Lake Baikal is due to necessity to resolve several problems in the following areas: fish abundance dynamics, reproduction of fish stock, creation of a biological basis for fisheries and study of fish ailments. Hence, a very promising is to develop methods of a complex monitoring of fish in Lake Baikal.

Baikal omul Coregonus migratorius (Georgi, 1775) is the main commercial species of Lake Baikal, thus the census of its population size and biomass is a goal of the rational nature resource management. The urgency of a more meticulous investigation of this species stock is driven by the current decrease of its abundance. Thereby the monitoring methods that do not need fish catch are in priority. Developing hydroacoustic methods, particularly to obtain equations of target strength dependence on omul size by reference to specific features of behavior of different morphoecological groups and age on a theoretical and practical basis would be promising. These methods were tested during a trawl-acoustic survey of Baikal omul stock assessment and distribution (Melnik et al., 2009).

The extension of the studies for the ice period will give new opportunities to improve the method in order to apply it as a monitoring technique of other pelagic fish species of Lake Baikal. A difficulty of evaluation of population size of pelagic sculpins (Cottoidei) by these methods is that the back echo strength from fish without a swim bladder is significantly lower than from those that have it. Besides, the sculpins are smaller than the omul, and they inhabit the maximum depths (up to $1600 \mathrm{~m}$ ). Nonetheless, the hydroacoustic 
technique can be and has to be adapted to the issue of monitoring of all pelagic species as a whole.

The environmental DNA (eDNA) quantification analysis is a method of evaluation of biomass of hydriobionts which is rapidly growing nowadays in addition to the hydroacoustic one. For the first time the potential of the method to detect vertebrates (particularly fish) in water samples by means of eDNA was demonstrated in 2008 (Ficetola et al., 2008). This tool is particularly important in monitoring rare and endangered species of fish and water invertebrates. Moreover, this technique has a potential of improving the detection sensitivity and decreasing of cost in the field use (Goldberg et al., 2011; Jerde et al., 2011; Thomsen et al., 2012). Its advantage is also a possibility to quickly get a full information about the biodiversity of a waterbody that is very important due to the lack of time for a thorough fish sampling during the field work (Jerde et al., 2011; Dejean et al., 2012; Pilliod et al., 2013; Sigsgaard et al., 2015; Hänfling et al., 2016; Yamamoto et al., 2016). This method is now evolving in three directions: detection of endangered species, tracking of invasive species and optimization for the field and laboratory conditions (Mahon et al., 2013; Wilcox et al., 2013; Barnes et al., 2014). The testing of the eDNA analysis for evaluation and monitoring of Baikal omul stock showed that the peculiarities of its distribution revealed by hydroacoustic method allows the species to be taken as a model for developing of eDNA analysis methods. The both approaches are complementary and enables the correction in the case of a study of actively migrating species. The development of eDNA analysis methods may serve a basis for a study of genetic polymorphism of fish in assemblies of various kind and related to their space distribution (Kirilchik et al., 2018). The implantation of the improved technology of the distance fish inventories (together with spawning population and young fish monitoring data) will provide a precise information on the current state of artificially reproduced populations; the information that is necessary to elaborate a correct strategy of commercial fishing.

The priority area of our ichthyologic studies is a recovery and conservation of rare and endangered fish species by means of artificial reproduction and development of innovative methods of cold-water breeding of Salmonidae and Acipenseridae in Siberian region (Sukhanova et al., 2011; Smirnov et al., 2015). Research in this direction suggests: creating test sites for short and long-term experiments on artificial reproduction and aquaculture on the basis of existing fisheries and aquarium complexes (upgrading the experimental base); carrying out fish-breeding and reclamation works on the ways of spawning migrations, restoring natural spawning sites; improving the methods of brood fish sampling for breeding purposes; creating of replenishable replacement and spawning schools of Baikal fish species that are endangered or decrease in number; developing technology of natural spawning in the channels of the cage culture fisheries. Development of aquaculture needs selection, diversification and increase of volume of high quality fish seed, e.g. by hybridization of whitefishes and introduction of the most robust and promising hybrids (Sukhanova et al., 2017).

Selection, hybridization and creation of a replenishable cryobank need development, introduction and improvement of methods of hormonal stimulation of spawning fish, cold storage of reproductive products, individual fish tagging (Suhanova et al., 2015; Sukhanova et al., 2017). Very promising can be the interspecies germ cell transplantation (GCN) adapted for whitefishes both for the study of reticulate evolution, conservation of species and populations of whitefishes, and for creation of new promising fish cultures. The innovative molecular GCT biotechnology allows a more effective use of females because the species of small size that quickly grow up and are easy to keep are selected as recipients (Majhi et al., 2014), and therefore contributes to optimization of many stage in artificial fish breeding and to preservation of biodiversity.

The rapid progress of fisheries worldwide confirms the importance of aquaculture for meeting the alimentary needs. The effective fish farms use innovative approaches based on progressive biotechnologies, new industrial techniques, dynamic marketing and competitive advantage. The studies of pathogenic bacteria in fish microflora and factors contributing to prevention of fish infectious diseases are necessary for science-based control of quality and safety of primary and final products (Abramova, 2004; Buller, 2004; Kirichenko et al., 2004). Change of trophic status of artificial ponds during the fish breeding causes blooms of saprophytic microorganisms, which lead to growth of incidences and excessive mortality among the fish. Therefore, the determination of key indicator species of regional pathogens by state-of-the-art methods of detection is an urgent and promising scientific objective. (Sukhanova et al., 2010; Dzyuba et al., 2011a; 2011b; 2012; 2013; 2014a-b; Belkova et al., 2014). Another rapidly developing area is the study of the associated microflora - an informative method for analyzing both the ecology of endemic Baikal species (Dzyuba et al., 2014a; 2014b; 2016; Belkova et al., 2015), and the objects of aquaculture (Belkova et al., 2017).

Molecular genetic methods are a reliable and convenient tool for solving many applied problems. In addition to the studies of the associated microflora, they are successfully used in the investigations of fish parasites (Denikina et al., 2016), and in the identification of fish prey (Kuznedelov and Dzyuba, 1999; Carreon-Martinez et al., 2011; Harms-Tuohy et al., 2016). This tool is very useful in analysis of highly digested gastric content, fish eggs, invertebrate cocoons etc. The advantage of the molecular genetic methods is the analysis of short DNA fragments present in the contents of the gastrointestinal tract of fish, even in the absence of material suitable for identification by morphological features. Molecular genetic methods are promising, and sometimes the only tool when conducting legal expertise, for example, of fish eggs or products during investigations of crimes against wildlife during the illegal fishing of valuable commercial fish.

Equally promising is the development of mobile remote systems for underwater video monitoring (Khanaev et al., 2000), prototype of instrument based 
on the EthoStudio software and holographic approach imitating tactile reaction on Baikal fish inhabiting different environments (Sapozhnikova et al., 2016; 2017a; 2017b). Possible consequences of anthropogenic impact include behavioral changes, worsening of sensory sensitivity, increased stress and lower growth rates of individuals (Sapozhnikova et al., 2017b). In turn, the adaptation of fish to different conditions (noise level, pressure, ground heterogeneity, changes of physical parameters with depth) causes a large variety of adaptations of the sense organs. The conditions of keeping rare and endangered fish species during artificial reproduction determine their further survival and affect the efficiency of the replenishment of commercial stock. The study of the mechanisms of adaptation of fish in the natural environment will allow the development of criteria for assessing their stability in aquaculture with constant monitoring of the environment (common garden experiments) (Sapozhnikova et al., 2017b; Sukhanova et al., 2017). The combination of ethological studies and morphological screening of fish sensory system during artificial cultivation helps to identify the most stress-resistant individuals and makes it possible to develop a system of ecological and morphological certification of fish, to select forms that are promising for high-tech industrial aquaculture. Thus, at present, studies of physiological processes affecting the behavior of fish become relevant. The combination of ethological studies and in-depth comprehensive morphological, molecular-genetic and physiological-biochemical screening of Baikal fish will help to solve the problems of biodiversity conservation under the constantly increasing anthropogenic load. Theoretically, such integrated work will allow a better understanding of the fundamental evolutionary processes responsible for the formation of behavioral adaptations, the creation and maintenance of genetic diversity within and between populations in the natural environment, as well as the development of recommendations for the introduction of state-of-the-art scientific monitoring into aquaculture.

The implementation of these research areas will bring the work on the study and preservation of fish biological diversity, as well as monitoring and management of the Baikal fish stock to a new orbit. In addition, the information obtained will provide a scientific and technological basis for the development of aquaculture in the Baikal region at the modern international level. However, all these are just a few initiatives that preserve the continuity of ichthyologic studies in Lake Baikal and testifying their significance in the new millennium.

\section{Acknowledgments}

This work was funded by budget projects of Federal Agency of Scientifc Organizations number 03452016-0002 (AAAA-A16-116122110066-1) "Molecular ecology and evolution of living systems of Central Asia during the global cliamatic change", RFBR and the Government of the Irkutsk region projects No 17-44388081 r_a and No 17-44-388106 r_a, project "Obtain- ing hightech aquaculture of whitefish ..." (Forum Baikal) at the "Experimental freshwater aquarium complex of Baikal hydrobionts".

\section{References}

Abramova L.S. 2004. Main areas of technological research of VNIRO. Applied Biochemistry and Technology of Hydrobionts: VNIRO Proceedings. Moscow: VNIRO Publishing 143: 9-16. (in Russian)

Barnes M.A., Turner C.R., Jerde C.L. et al. 2014. Environmental conditions influence eDNA persistence in aquatic systems. Environmental Science \& Technology 48: 1819-1827. DOI: $10.1021 /$ es 404734p

Belkova N.L., Denikina N.N., Sukhanova E.V. et al. 2014. Method of sample preparation for the selective detection of live and viable cells that are potential pathogens of fishes. Water: chemistry and ecology 11: 77-82. (in Russian)

Belkova N.L., Denikina N.N., Dzyuba E.V. 2015. Study of intestinal microbiome of Comephorus dybowski Korotneff, 1904. Biology Bulletin 5: 544-551. DOI: 10.1134/ S1062359015050039

Belkova N., Sidorova T., Glyzina O. et al. 2017. Gut microbiome of juvenile coregonid fishes: comparison of sympatric species and their F1 hybrids. Fundamental and Applied Limnology / Archiv für Hydrobiologie 189: 279-290. DOI: 10.1127/fal/2016/0804

Buller N.B. 2004. Bacteria from fish and other aquatic animals: a practical identification manual. Oxfordshire: CABI publishing.

Carreon-Martinez L., Johnson T.B., Ludsin S.A. et al. 2011. Utilization of stomach content DNA to determine diet diversity in piscivorous fishes. Journal of Fish Biology 78: 1170-1182. DOI: 10.1111/j.1095-8649.2011.02925.x.

Dejean T., Valentini A., Miquel C. et al. 2012. Improved detection of an alien invasive species through environmental DNA barcoding: the example of the American bullfrog Lithobates catesbeianus. Journal of Applied Ecology 49: 953-959. DOI: 10.1111/j.1365-2664.2012.02171.x

Denikina N., Nebesnykh I., Maikova O. et al. 2016. Genetic diversity of Diplomonadida in fish of the genus Coregonus from south- eastern Siberia. Acta Parasitologica 61: 299-306. DOI: $10.1515 / a p-2016-0040$

Dzyuba E.V., Denikina N.N., Sukhanova E.V. et al. 2011. High sensitivity detection of etiological agents of bacterial ulcerous syndrome of Baikalian omul Coregonus migratorius (Georgi, 1775). The Bulletin of Irkutsk State University. Series «Biology. Ecology» 4: 46-52. (in Russian)

Dzyuba E.V., Denikina N.N., Kondratistov Yu.L. et al. 2012. Approbation of the system of highly sensitive detection of pathogenic microorganisms in the aquaculture of ordinary carp Cyprinus carpio Linnaeus, 1758. Izvestia of Samara Scientific Center of the Russian Academy of Sciences 14: 18831886. (in Russian)

Dzyuba E.V., Denikina N.N., Sukhanova E.V. et al. 2013. Complex analysis of pathogenic microorganisms of Esox lucius Linnaeus, 1758. Water: chemistry and ecology 3: 113-117. (in Russian)

Dzyuba E.V., Denikina N.N., Pastukhov V.V. et al. 2014a. Development and validation of the molecular-and- genetic technique for diagnosing pathogenic microorganisms on external coatings of fishes. Water: chemistry and ecology 2: 57-62. (in Russian)

Dzyuba E.V., Sukhanova E.V., Denikina N.N. et al. 2014b. Comparative analysis of gut microbiocenoses of salmonid fish with different feeding strategies. Fundamental Research 11: 2429-2433. (in Russian) 
Dzyuba E.V., Belkova N.L., Denikina N.N. 2016. A study of the intestinal microbiomes of the Lake Baikal oilfishes (Cottoidei, Comephoridae). Biology Bulletin 6: 658-662. DOI: 10.1134/S106235901606008X

Ficetola G.F., Miaud C., Pompanon F. et al. 2008. Species detection using environmental DNA from water samples. Biology Letters 4: 423-425. DOI: 10.1098/rsbl.2008.0118

Goldberg C.S., Pilliod D.S., Arkle R.S. et al. 2011. Molecular detection of vertebrates in stream water: a demonstration using Rocky Mountain tailed frogs and Idaho giant salamanders. PLoS One 6: e22746. DOI: 10.1371/journal. pone.0022746

Hänfling B., Handley L.L., Read D.S. et al. 2016. Environmental DNA metabarcoding of lake fish communities reflects long-term data from established survey methods. Molecular Ecology 25: 3101-3119. DOI: 10.1111/mec.13660

Harms-Tuohy C.A., Schizas N.V., Appeldoorn R.S. 2016. Use of DNA metabarcoding for stomach content analysis in the invasive lionfish Pterois volitans in Puerto Rico. Marine Ecology Progress Series 558: 181-191. DOI: 10.3354/ meps11738.

Jerde C.L., Mahon A.R., Chadderton W.L. et al. 2011. "Sight-unseen" detection of rare aquatic species using environmental DNA. Conservation Letters 4: 150-157. DOI: 10.1111/j.1755-263X.2010.00158.x

Khanaev I.V., Melnik N.G., Timoshkin O.A. et al. 2000. Application of deep water video monitoring system during scientific research in Lake Baikal. In: Third Verschagin Conference, pp. 254.

Kirichenko S.G., Kurlapova L.D., Khromykh N.N. et al. 2004. Valuation of products from hydrobionts // Applied Biochemistry and Technology of Hydrobionts: VNIRO Proceedings. Moscow: VNIRO Publishing 143: 42-44. (in Russian)

Kirilchik S.V., Makarov M.M., Anoshko P.N. et al. 2018. Testing method quantitative eDNA analysis for stock assessment and monitoring of Baikal omul populations. International Journal of Applied and Basic Research 6: 98-102. DOI: 10.17513/mjpfi.12300 (in Russian)

Kuznedelov K.D., Dzyuba E.V. 1999. Specific accessories of Baikal planaria cocoons from Baikal black grayling stomach by comparative analysis of nucleotide sequences of gene of ribosome RNA. Journal of General Biology 60: 445-450. (in Russian)

Mahon A.R., Jerde C.L., Galaska M. et al. 2013. Validation of eDNA surveillance sensitivity for detection of Asian carps in controlled and field experiments. PLoS ONE 8: e58316. DOI: 10.1371/journal.pone.0058316

Majhi S.K., Hattori R.S., Rahman S.M. et al. 2014. Surrogate Production of Eggs and Sperm by Intrapapillary Transplantation of Germ Cells in Cytoablated Adult Fish. PLoS ONE 9: e95294. DOI: 10.1371/journal.pone.0095294

Melnik N.G., Smirnova-Zalumi N.S., Smirnov V.V. et al. 2009. Hydroacoustic survey of baikal omul. Novosibirsk: Nauka. (in Russian)

Pilliod D.S., Goldberg C.S., Arkle R.S. et al. 2013. Estimating occupancy and abundance of stream amphibians using environmental DNA from filtered water samples. Canadian Journal of Fisheries and Aquatic Sciences 70: 1123-1130.

\section{DOI: $10.1139 /$ cjfas-2013-0047}

Sapozhnikova Yu.P., Klimenkov I.V., Khanaev I.V. et al. 2016. Ultrastructure of saccular epithelium sensory cells of four sculpin fish species (Cottoidei) of Lake Baikal in relation to their way of life. Journal of Ichthyology 56: 289-297. DOI: 10.1134/S0032945216010136

Sapozhnikova Yu.P., Belous A.A., Makarov M.M. et al. 2017a. Ultrastructural correlates of acoustic sensitivity in Baikal coregonid fishes. Fundamental and Applied Limnology / Archiv für Hydrobiologie 189: 267-278. DOI: 10.1127/ fal $/ 2017 / 0810$

Sapozhnikova Yu.P., Tyagun M.L., Makarov M.M. et al. $2017 \mathrm{~b}$. Effect of intense underwater sound on auditory organs of Baikal coregonid fishes in aquaculture. Aktualnye problemy nauki Pribaykalya [Key Problems of the Science in Pribaikalye] 2: 188-194. (in Russian)

Sigsgaard E.E., Carl H. Mwller P.R., Thomsen P.F. 2015. Monitoring the near-extinct European weather loach Misgurnus fossilis in Denmark by combining traditional fishing surveys and environmental DNA from water samples. Biological Conservation 183: 46-52. DOI: 10.1016/j.biocon.2014.11.023

Smirnov V.V., Smirnova-Zalumi N.S., Sukhanova L.V. et al. 2015. To the measures on preservation of Baikal omul (Coregonus migratorius) stock. Vestnik rybokhozjajstvennoj nauki [Bulletin of Fishery Science] 2: 42-45. (in Russian)

Sukhanova E.V., Dzyuba E.V., Denikina N.N. et al. 2010. Definition of indicating microorganisms for monitoring fishes infectious diseases on the example of Perca fluviatilis (Lake Arahley, Zabaikalskiy kray). Izvestia of Samara Scientific Center of the Russian Academy of Sciences 12: 1156-1161. (in Russian)

Sukhanova L.V., Zhuravlyov O.I., Smirnov V.V. et al. 2011. Prospects for abundance recovery of baikal lacustrine-riverine white-fish and its application. Rybovodstvo i rybnoe hozjajstvo [Fish farming and Fisheries] 10: 26-28.

Suhanova L.V., Smirnov V.V., Teterina V.I. et al. 2015. Synchronization of ovulation in Baikal omul (Coregonus migratorius, Georgi) using human chorionic gonadotropin. Water: chemistry and ecology 12: 125-130. (in Russian)

Sukhanova L.V., Smirnov V.V., Smirnova-Zalumi N.S. et al. 2017. Artificial hybrids of Lake Baikal coregonid fishes some experience (Coregonus sp.). Aktualnye problemy nauki Pribajkalja [Key Problems of the Science in Pribaikalye] 2: 215-221. (in Russian)

Thomsen P.F., Kielgast J., Iversen L.L. et al. 2012. Monitoring endangered freshwater biodiversity using environmental DNA. Molecular Ecology 21: 2565-2573. DOI: 10.1111/j.1365-294X.2011.05418.x

Wilcox T.M., McKelvey K.S., Young M.K. et al. 2013. Robust detection of rare species using environmental DNA: the importance of primer specificity. PLoS One 8: e59520. DOI: 10.1371/journal.pone.0059520

Yamamoto S., Minami K., Fukaya K. et al. 2016. Environmental DNA as a "Snapshot" of fish distribution: a case study of Japanese Jack Mackerel in Maizuru Bay, Sea of Japan. PLoS ONE 11: e0149786. DOI: 10.1371/journal.pone.0149786 